\title{
Beyond Symbolism
}

\author{
Problems and Prospects with Prosecuting Environmental \\ Destruction before the ICC
}

\author{
Eliana Teresa Cusato*
}

\begin{abstract}
In September 2016, the International Criminal Court (ICC) Prosecutor issued a new policy paper detailing the Office of the Prosecutor's (OTP) priorities for case selection and prioritization, including giving a 'particular consideration to prosecuting Rome Statute crimes that are committed by means of, or that result in, inter alia, the destruction of the environment, the illegal exploitation of natural resources or the illegal dispossession of land'. This new commitment of the OTP in fighting environmental devastation has been received enthusiastically by civil society and alleged victims. Indeed, few would disagree that protecting the environment against harmful conduct and conserving the world's natural resources are some of the most compelling challenges faced by the international community. Further, the negative impact of environmental destruction on human rights, and peace and security, is a matter of concern for many international institutions, including the United Nations Security Council. This article considers the merits and limits of prosecuting environmental destruction before the ICC. It contends that the significance and practical implications of the OTP's green shift ought to be appreciated against the constraints posed by existing criminal provisions (which have already received attention in the literature) and, more significantly, factual and structural challenges that have been more peripheral in the academic debate. Accordingly, the article suggests possible ways to overcome some of these obstacles. The article concludes by reflecting on the necessity to strike a balance between the OTP's commendable policy shift, victims' and environmental activists' expectations, and the ICC's possible contribution to 'environmental justice'.
\end{abstract}

\footnotetext{
* Ph.D. Candidate, Faculty of Law, National University of Singapore. This article draws from the ongoing research for my doctoral dissertation, under the supervision of Assistant Professor Cheah Wui Ling. I am thankful to the anonymous reviewers for their thoughtful comments. Errors and omissions remain my own. [eliana.cusato@u.nus.edu]
} 
'Sognai talmente forte che mi uscì il sangue dal naso'

F. De Andrè, Fiume Sand Creek

\section{Introduction}

According to the Tri Hita Karana philosophy, which originates from Bali, three harmonious relationships must be cultivated for the well-being and prosperity of the whole humanity: human to human, human to Gods and human to the environment. Decades of unsustainable economic growth, aggressive extraction of natural resources, and egoistic consumption patterns (particularly in the Global North) have deteriorated the bond between humans and the environment. Although few may deny the urgency of the matter, environmental degradation and critical resource scarcity are some of the most compelling challenges that the international community is facing — which, if not taken seriously, may well endanger peace and security, and the very survival of humankind.

Environmental protection is a cross-sectoral problem, with implications inter alia for human rights, security, and trade regimes. Hence, from a legal perspective, different sub-fields of international law and enforcement mechanisms are relevant to confronting environmental concerns. The 'global' nature of the protected interests and the erga omnes character of many international environmental obligations are the main arguments in favour of the international criminalization of certain environmental harms. ${ }^{1}$ Indeed, some treaties impose an obligation on states to criminalize within their domestic systems acts that may result in severe damage to the environment. ${ }^{2}$ In accordance with the subject of this symposium, the focus of this article is on international criminal law stricto sensu

\footnotetext{
${ }^{1}$ For a comprehensive account of the arguments in favour and against the international criminalization of environmental concerns, see e.g. F. Mégret, 'The Problem of an International Criminal Law of the Environment', 36 Columbia Journal of Environmental Law (2011) 195.

${ }^{2}$ E.g. Convention on International Trade in Endangered Species of Wild Fauna and Flora (CITES); Basel Convention on the Control of Transboundary Movements of Hazardous Wastes and their Disposal.
} 
and, in particular, on 'core crimes' set forth in the Statute of the International Criminal Court (ICC).

The Preamble to the Statute solemnly affirms that an independent permanent International Criminal Court 'with jurisdiction over the most serious crimes of concern to the international community as a whole' is created 'for the sake of the present and future generations'. Yet a very limited reference to the protection of the environment is made within the Statute's provisions. This is not particularly surprising considering the predominantly anthropocentric character of international criminal law (and the laws of war and human rights law with which it is interwoven), the relatively recent emergence of environmental concerns in the international arena, and states' preference for other forms of regulation in this respect (e.g. international environmental law and 'soft approaches').

Conversely, the academic debate on a possible role for international criminal law (and more specifically the ICC) in advancing the protection of the environment in peace and wartimes has been quite prolific, especially in the last decade or so. Hence, to those familiar with these academic endeavours and nongovernmental organization (NGO) advocacy efforts, the 2016 Policy Paper issued by the ICC Office of the Prosecutor (OTP) did not come as a total surprise. This document detailed the Prosecutor's priorities for case selection, including a 'particular consideration to prosecuting Rome Statute crimes that are committed by means of, or that result in, inter alia, the destruction of the environment, the illegal exploitation of natural resources or the illegal dispossession of land'. ${ }^{3}$ More precisely, in assessing the gravity of crime(s) - one of the criteria for case selection - the OTP reaffirmed that it will consider the scale, nature, manner of commission and impact of the crimes. ${ }^{4}$ Environmental concerns inform both the

\footnotetext{
${ }^{3}$ OTP, Policy Paper on Case selection and Prioritisation, 15 September 2016, available online at https://www.icc-cpi.int/itemsDocuments/20160915 OTP-Policy Case-Selection_Eng.pdf (visited 25 May 2017) ('2016 Policy Paper'), § 41. One may wonder whether the use of the term 'destruction' of the environment, in lieu (for instance) of degradation, has a particular meaning or not. What the term suggests, anyway, is that the OTP will give particular consideration to the most severe forms of environmental harms, those that result not just in the temporary loss of environmental values, but in long-term and potentially permanent damage.

${ }^{4}$ Ibid., § 37 .
} 
manner of commission of the crimes (i.e. 'the use of ... crimes committed by means of, or resulting in, the destruction of the environment ${ }^{5}$ ) and the impact of the crimes, which will be evaluated in light of 'the environmental damage inflicted on the affected community'. ${ }^{6}$ The ICC's possible future engagement with the three environmental wrongs mentioned (i.e. destruction of the environment, illegal natural resource exploitation, and land dispossession) raises hope, but also several questions.

This article considers the merits and limits of prosecuting environmental destruction before the ICC. It contends that the significance and practical implications of the OTP's green shift ought to be appreciated against the constraints posed by existing provisions (which have already received attention in the literature) and, more significantly, factual and structural challenges that have been more peripheral in the academic debate. Accordingly, this article suggests possible ways to overcome some of these obstacles.

The remainder of the article proceeds as follows. Part II recapitulates the debate on the capacity of international criminal law provisions to proscribe environmental harms committed in wartime and peacetime. The analysis will be informed by the reference in the 2016 Policy Paper to two ways in which environmental concerns may be addressed in the future practice of the Office: first, through the prosecution of Rome Statute crimes 'that are committed by means of ... the destruction of the environment'; second, through the prosecution of crimes 'that result in the destruction of the environment.' Part III ponders the practical implications of the 2016 Policy Paper for environmental protection. First, it traces additional reasons (beyond the letter of the law) for the limited engagement of international criminal justice with 'environmental crimes', notably the problems with causation and evidence gathering. Second, it questions whether and to what extent the functions and remedies of international criminal justice can be reconciled with those of environmental preservation. Part IV concludes.

\footnotetext{
${ }^{5}$ Ibid., $\S 40$.

${ }^{6}$ Ibid., $\$ 41$.
} 


\section{The Rome Statute and Environmental Concerns: Origins and Evolution of the Debate on Environmental Protection through International Criminal Law}

\section{A. The Environment as a 'Victim' of International Crimes}

The 2016 Policy Paper suggests two ways in which environmental matters may be addressed in future by the OTP, which reflect the traditional divide between anthropocentric and ecocentric perspectives on environmental protection: first, through the prosecution of Rome Statute crimes 'that are committed by means of ... the destruction of the environment'; second, through the prosecution of crimes 'that result in the destruction of the environment'. In the former, the natural environment is the means by which humanitarian norms, upholding human values, are breached; in the latter, nature itself can be considered as the direct or indirect beneficiary of the protection. This section maps out the historical origins of the efforts to criminalize acts that result in the destruction of the environment, before considering the most recent academic debate on the sole ecocentric provision in the ICC Statute.

The term often used to describe the intentional and most dramatic form of environmental devastation, susceptible of international criminal punishment, is 'ecocide'. The birth of the concept dates back to the Vietnam War, when it was employed to depict the severe environmental and human impact of certain US military tactics, most notably the massive use of herbicides (e.g. Agent Orange) to destroy forests and crops. The term was coined by a plant biologist, Arthur Galston, to characterize the 'willful, permanent destruction of environments in which people can live in a manner of their choosing'. At a conference on War

\footnotetext{
${ }^{7}$ D. Zierler, Invention of Ecocide: Agent Orange, Vietnam, and the Scientists Who Changed the Way We Think About the Environment (University of Georgia Press, 2011), at 15.
} 
Crimes and the America Conscience held in 1970, Galston condemned Operation Ranch Hand and asked the international community, through the United Nations, to come together against ecocide, just as the world did after World War II against genocide and crimes against humanity. ${ }^{8}$

Richard Falk developed this set of ideas and framed them in legal terms. In his 1973 publication, Environmental Warfare and Ecocide: Facts, Appraisal and Proposals, having identified the limits of international humanitarian law in the area of environmental protection, Falk called for the development of new legal instruments, namely an International Convention on the Crime of Ecocide and a Draft Protocol on Environmental Warfare. ${ }^{9}$ Falk argued that such a normative agenda had gained momentum, as the 'public outrage over the desecration of the land' in Vietnam 'creates a target of opportunity comparable to Nuremberg'. ${ }^{10}$ And 'just as the Genocide Convention came along to formalize part of what has already been carried and punished at Nuremberg, so an Ecocide Convention could help carry forward into the future a legal condemnation of environmental warfare in Indochina'. ${ }^{11}$ Falk's proposed Convention on the Crime of Ecocide defined ecocide as encompassing 'acts committed with intent to destroy, in whole or in part, a human ecosystem', in peacetime or wartime. ${ }^{12}$

Both Galston's and Falk's proposals for the expansion of international law to proscribe attacks against the environment under the crime of ecocide were influenced by the dramatic experience of the Vietnam War. Beyond the short parenthesis of Article 26 of the 1991 ILC Draft Code on Crimes Against Peace and Security of Mankind, ${ }^{13}$ the narrower focus on punishing environmental

${ }^{8}$ B. Leebaw, 'Scorched Earth: Environmental War Crimes and International Justice', 12 Perspectives on Politics (2014) 770, at 777.

${ }^{9}$ R. Falk, 'Environmental Warfare and Ecocide: Facts, Appraisal and Proposals', 4 Bulletin of Peace Proposals (1973) 80.

${ }^{10} \mathrm{Ibid}$., at 84 .

${ }^{11}$ Ibid., at 84 .

${ }^{12}$ Ibid., at 93, Appendix I.

${ }^{13}$ Report of the International Law Commission on the Work of its Forty-Third Session, UN Doc. A/CN.4/SER.A/1991/Add.1 (Part 2), Art. 26: 'Wilful and severe damage to the environment' ('[a]n individual who wilfully causes or orders the causing of widespread, long-term and severe damage to the natural environment shall, on conviction thereof, be sentenced to ...'). Art. 26 was later deleted from the final version of the Draft Code. 
devastation in times of war has been carried on until the present day. Several factors may explain this approach, notably the strong bonds that tie international criminal law and international humanitarian law together, and the parallel emergence of international environmental law, considered by most states as the preferred avenue to address peacetime environmental concerns.

The Rome Statute, thus, built upon earlier provisions in the laws of armed conflict, ${ }^{14}$ and introduced the first ecocentric war crime. ${ }^{15}$ Article 8(2)(b)(iv) prohibits, in the context of international armed conflict, 'intentionally launching an attack in the knowledge that such attack will cause ... widespread, long-term and severe damage to the natural environment, which would be clearly excessive in relation to the concrete and direct overall military advantage anticipated'. Undoubtedly, introducing a war crime punishing harm to the environment has a strong symbolic value: it recognizes that environmental integrity is a fundamental interest that deserves protection during armed conflict, and that violating this interest entails the most severe sanction, criminal responsibility.

Yet scholars drew attention to several limitations of Article 8(2)(b)(iv), notably: a high threshold of damage, the vagueness of the terms employed, the reliance upon the proportionality test, the mental element requiring strict intentionality, and its application only in the context of international armed conflict. ${ }^{16}$ Whilst it is impracticable to explore such arguments in detail here, it is

\footnotetext{
${ }^{14}$ See Convention on the Prohibition of Military or Any Other Hostile Use of Environmental Modification Techniques ('ENMOD Convention') (10 December 1976); see also Additional Protocol I, Arts 35(3) (prohibiting 'methods or means of warfare which are intended, or may be expected, to cause widespread, long-term and severe damage to the natural environment'), 55 ('[c]are shall be taken in warfare to protect the natural environment against widespread, long-term and severe damage. This protection includes a prohibition of the use of methods or means of warfare which are intended or may be expected to cause such damage to the natural environment and thereby to prejudice the health or survival of the population. Attacks against the natural environment by way of reprisals are prohibited').

${ }^{15}$ Violations of Arts 35(3) and 55(1) of Additional Protocol I are not listed as grave breaches, whereas the ENMOD Convention does not impose criminal liability in case of violation of its provisions.

${ }^{16}$ E.g. J.C. Lawrence and K.J. Heller, 'The First Ecocentric Environmental War Crime: The Limits of Article 8(2)(b)(iv) of the Rome Statute', 20 Georgetown International Environmental Law Review (GIELR) (Fall 2007) 61.
} 
useful to outline the core concerns raised by commentators, to better appreciate the significance of the OTP's green shift.

First, the actus reus of Article 8(2)(b)(iv) requires the launching of an attack (but the environment does not have to be the target of the attack), with the knowledge that it will cause 'widespread, long term and severe damage to the natural environment'. Although the concept of 'attack' is not limited to a single act of warfare, it is circumscribed to a certain time and space, hence it is narrower and less flexible than the expression 'methods and means of warfare' in Additional Protocol I. ${ }^{17}$ The three qualifiers are conjunctive and there is no definition of those terms in the Rome Statute or its Elements of Crimes. The ENMOD Convention employs similar language, and provides a definition of the three concepts, but these definitions are apparently limited to their specific context. ${ }^{18}$ The travaux préparatoires to Additional Protocol I qualify 'long-term' as damage 'that lasts decades', but are silent on the exact meaning of 'widespread' and 'severe'. 19

Second, the damage to the natural environment has to be "clearly excessive in relation to the concrete and direct overall military advantage anticipated'. The provision reproduces the proportionality principle familiar from the traditional jus

\footnotetext{
${ }^{17}$ I. Paterson, 'The Natural Environment in Times of Armed Conflict: A Concern for International War Crimes Law?' 22 Leiden Journal of International Law (2009) 325, at 337.

${ }^{18}$ In the Understanding regarding the ENMOD Convention, annexed to the treaty, the adjectives 'widespread', 'long-lasting' and 'severe' are defined as follows: 'widespread: encompassing an area of the scale of several hundred square kilometres'; 'long-lasting: lasting for a period of months, or approximately, a season'; 'severe: involving serious or significant disruption or harm to human life, natural and economic resources or other assets'. The treaty clearly states that this interpretation is limited to the ENMOD Convention and does not apply to the 'same or similar terms used in different agreements'. It is noteworthy that the definition of 'severe' brings anthropocentric concerns back into the provisions. On the point see e.g. M. Drumbl, 'International Human Rights, International Humanitarian Law and Environmental Security, Can the International Criminal Court Bridge the Gaps?' 6 ILSA Journal of International \& Comparative Law (19992000) 305 , at 316

${ }^{19}$ Lawrence and Heller, supra note 16, at 73. Some commentators have suggested that the term may be interpreted as follows: 'widespread' as encompassing at least an entire region of several hundreds of kilometres; 'severe' as causing death, ill-health or loss of sustenance to thousands of people, at present or in the future. See A. Leibler, 'Deliberate Wartime Environmental Damage: New Challenges for International Law', as cited by Steven Freeland, Addressing the International Destruction of the Environment during Warfare Under the Rome Statute of the International Criminal Court (Intersentia, 2015), at 87.
} 
in bello. By doing so, however, Article 8(2)(b)(iv) represents a step backward compared with the protection against environmental damage in Additional Protocol I. ${ }^{20}$ Not only does it add uncertainty by referring to proportionality at all, ${ }^{21}$ but it also requires the damage to the natural environment to be 'clearly excessive' (not just excessive) in relation to the military advantage anticipated. ${ }^{22}$

Third, in terms of mens rea, Article 8(2)(b)(iv) requires knowledge and intent that the conduct (launching an attack) will cause widespread, long-lasting and severe damage to the environment, and that such damage would be disproportionate ('clearly excessive') in relation to the military advantage anticipated. ${ }^{23}$ Negligent, wilfully blind or reckless conduct is outside the scope of the norm. ${ }^{24}$ Finally, and perhaps most significantly, the protection of the natural environment is not only limited to armed conflict but only to international armed conflict.

On the basis of these limitations in the text of Article 8(2)(b)(iv), a range of proposals have been put forward by scholars to enhance the protection of the environment from harmful conduct. More conservative approaches contend that existing war crimes applicable in non-international and international armed conflict may be used to impose liability for acts resulting, inter alia, in

\footnotetext{
${ }^{20}$ Under the special regime of Art. 55, Additional Protocol I, the three elements of 'widespread, long-term and severe damage' are introduced in lieu of the proportionality test. Should the three criteria be met, the attack will violate the Protocol, even if proportional. See Y. Dinstein, The Conduct of Hostilities Under the Law of International Armed Conflict (Cambridge University Press, 2004), at 186. It should be noted, however, that violating Art. 55 of Additional Protocol I does not result in individual criminal responsibility: see Art. 85.

${ }^{21}$ E.g. M. Gillett, 'Environmental Damage and International Criminal Law', in S. Jodoin and M.C. Cordonier Segger (eds), Sustainable Development, International Criminal Justice and Treaty Implementation (Cambridge University Press, 2013) 73, at 83.

${ }^{22}$ A. Cassese, International Criminal Law (Oxford University Press, 2003), at 60-61, emphasis added.

${ }^{23}$ It has been observed that, in the ICC Elements of Crimes, the 'military advantage anticipated' refers to 'a military advantage that is foreseeable by the perpetrator at the relevant time', which should therefore be evaluated on a subjective basis. It is not evident whether the "clearly excessive' requirement is based on objective or subjective standards. The Elements of Crimes require the perpetrator to 'make the value judgment', but they also call for 'an evaluation of that value judgment' to be based on the information available to the perpetrator at the time. See Lawrence and Heller, supra note 16, at 83.

${ }^{24}$ Drumbl, supra note 18, at 322.
} 
environmental degradation. ${ }^{25}$ This offers the advantage of relying on established provisions in the laws of armed conflict, already tested before international criminal fora. However, other commentators contend that such a solution is inadequate to address pure ecocentric concerns, and suggest amending Article $8(2)(\mathrm{b})(\mathrm{iv}){ }^{26} \mathrm{~A}$ third approach goes further and proposes the creation a new genus of 'crimes against the environment' to punish the destruction of the natural environment in armed conflict. ${ }^{27} \mathrm{~A}$ final, more radical perspective seeks to criminalize severe environmental damage even outside armed conflict. ${ }^{28}$ Whether those proposals will receive support from the international community of States remains to be seen; for the time being, the OTP will have to rely on the narrow text of Article 8(2)(b)(iv) or other war crimes provisions to prosecute conduct that result in environmental damage.

\section{B. Environmental Destruction as a Means to Commit International Crimes}

The second way in which environmental concerns may be addressed by the OTP in the future is through prosecuting crimes that are committed by means of environmental destruction. In such a situation, the interest protected by the norm criminalizing a certain behaviour is not the integrity of the environment per se, but fundamental human values, and environmental considerations are only instrumental in upholding these values. The OTP's position is coherent with, and

\footnotetext{
${ }^{25}$ E.g. C. Bruch, 'The Environmental Law of War, All's not Fair in (Civil) War: Criminal Liability for Environmental Damage in Internal Armed Conflict', 25 Vermont Law Review (2001) 695, at 718-719 (referring to provisions in the Rome Statute criminalizing attacks against civilian objects and destruction of enemy property not justified by military necessity).

${ }^{26}$ E.g. Lawrence and Heller, supra note 16, at 88 (proposing, in particular, clarifying the meaning of 'widespread, long-term and severe', lowering the proportionality test, making the subjective element more objective, and extending the provision to non-international armed conflict).

${ }^{27}$ Freeland, supra note 19, at 219-287 (proposing 'crimes against the environment' characterized by: anticipatory protection of the environment, as the actus reus does not require that 'actual harm' to the environment is 'achieved'; application both in international and non-international armed conflicts; defining 'widespread', 'long-term' and 'severe' as disjunctive requirements of environmental damage; penalizing a non-exclusive list of environmental damage; encompassing dolus directus, dolus eventualis and willful blindness within the mens rea).

${ }^{28}$ E.g. S. Jodoin, 'Conclusion: Protecting the Rights of Future Generations through Existing and New International Criminal Law', in Jodoin and Cordonier Segger (eds), supra note 21, 346, at 346; F. Mégret, 'The Case for a General International Crime Against the Environment', in Jodoin and Cordonier Segger (eds), ibid., at 50.
} 
perhaps informed by, literature arguing that genocide and crimes against humanity may well be employed to prosecute episodes of environmental degradation, when they are a means to perpetrate a humanitarian atrocity. ${ }^{29}$ According to Tara Weinstein, such an approach is not only feasible but builds on the precedent of the Akayesu case before the International Criminal Tribunal for Rwanda, where rape was considered as a means to commit genocide. Similarly, 'environmental destruction can be prosecuted as an accelerator of genocide or crimes against humanity' ${ }^{30}$

There is also already some precedent in the ICC's own practice. In Al Bashir, the Prosecutor sought the arrest of the defendant for genocide for having destroyed 'all the target groups' means of survival, poison sources of water including communal wells, destroy water pumps, steal livestock and strip the towns and villages of household and community assets'. ${ }^{31}$ Initially, the majority of judges of Pre-Trial Chamber I dismissed the allegation because of the lack of 'reasonable grounds to believe that such a contamination was a core feature of their attacks'. ${ }^{32}$ However, in a second decision on the application for a warrant of arrest, the Pre-Trial Chamber held that 'the act of contamination of water pumps and forcible transfer, coupled by resettlement by member of other tribes, were committed in furtherance of a genocidal policy and that the conditions of life inflicted on the Fur, Masalit and Zaghawa groups were calculated to bring about the group's physical destruction of part of those ethnic groups' ${ }^{33}$ The Pre-Trial

\footnotetext{
${ }^{29}$ E.g. T. Weinstein, 'Prosecuting Attacks that Destroy the Environment: Environmental Crimes or Humanitarian Atrocities', 17 GIELR (2004-2005) 697.

${ }^{30}$ Ibid., at 714-716 (examining the case of the Marsh Arabs, a Muslim Shi'a group living in Southern Iraq, that suffered direct killings and more indirect attacks including the draining of the Mesopotamian Marshes, which destroyed the ecosystem where they had been living for thousands of years, resulting in widespread deaths and forced resettlements).

${ }^{31}$ Public Redacted Version of the Prosecutor's Application under Article 58, Situation in Darfur (ICC-02/05-157-AnxA), Office of the Prosecutor, 14 July 2008, § 14.

${ }^{32}$ Decision on the Prosecution's Application for a Warrant of Arrest against Omar Hassan Ahmad Al Bashir, Al Bashir (ICC-02/05-01/09-3), Pre-Trial Chamber, 4 March 2009, § 93.

${ }^{33}$ Second Decision on the Prosecution's Application for a Warrant of Arrest against Omar Hassan Ahmad Al Bashir, Al Bashir (ICC-02/05-01/09-94), Pre-Trial Chamber, 12 July 2010, § 38 (emphasis added).
} 
Chamber thus found a nexus between the underlying environmental harm (water contamination) and the crime of genocide.

The prospects for testing the genocide charges against Al Bashir before the Pre-Trial and Trial Chambers are not encouraging, at least in the near future. Nonetheless, the Prosecutor's approach appears promising and, in principle, there is no reason why it cannot be replicated in the future. Undoubtedly, the critical element in bringing a charge for genocide concerns proof the special intent (i.e. 'to destroy, in whole or in part, a national, ethnical, racial or religious group'), which must accompany the commission of the underlying offence. In the case of environmental destruction, arguably the most pertinent would be 'deliberately inflicting on the group conditions of life calculated to bring about its physical destruction in whole or in part'. Yet in the majority of peacetime cases, governments will seek to justify environmental degradation and its adverse humanitarian effects pursuant to development concerns, hence raising the bar in proving the dolus specialis. ${ }^{34}$

In addition to genocide, environmental destruction can be 'used' to commit crimes against humanity, such as extermination, forcible transfer of population, persecution, and other inhuman acts. Persecution, which is defined as 'the intentional and severe deprivation of fundamental rights contrary to international law by reason of the identity of the group or collectivity', appears particularly relevant. ${ }^{35}$ There should be no doubt that critical resource scarcity, such as lack of access to clean water or food, resulting from serious environmental degradation, constitutes a breach of fundamental human rights.

Should the OTP decide to pursue this avenue, ${ }^{36}$ the Prosecutor may be able to rely on the argumentative tools developed by some scholars. ${ }^{37}$ At the same time,

\footnotetext{
${ }^{34}$ D. Sharp, 'Prospects for Environmental Liability in the International Criminal Court', 18 Virginia Environmental Law Journal (1999) 217, at 234.

${ }^{35}$ Art. 7(2)(g) ICCSt.

${ }^{36}$ A possible test-case for crimes against humanity in the context of environmental wrongs, broadly defined, is the communication submitted in October 2014 to the ICC Prosecutor accusing the Cambodian authorities of crimes against humanity through systematic land-grabbing and deforestation. For an analysis of how the 2016 Policy Paper might affect the interpretation of the constitutive elements of crimes against humanity committed by means of, or resulting in damage
} 
as with genocidal intent, the main constraint on applying these provisions to sanction environmental damage as the means to commit crimes against humanity lies in the contextual elements set forth in Article 7(1), namely the existence of a widespread or systematic attack, and the knowledge requirement. ${ }^{38}$

\title{
C. The OTP's Case Selection Policy and Implications for Environmental Protection
}

\author{
1. Beyond the Limits of Substantive Rules: the Need to Overcome Factual \\ and Evidentiary Challenges
}

It is safe to say that, until now, the judicial treatment of environmental concerns by international criminal tribunals has been limited. With the exception of few cases from the post-World War II Tribunals, ${ }^{39}$ and the Al-Bashir case at the ICC,

to, the environment, and preliminary reflections on the situation in Cambodia, see L. Prosperi and J. Terrosi, 'The Impact of Environmental Damage on the Selection and Prioritization of Cases before the International Criminal Court', in this issue of the Journal.

${ }^{37}$ E.g. Weinstein, supra note 29; T. Smith, 'Creating a Framework for the Prosecution of Environmental Crimes in International Criminal Law', in W.A. Schabas, Y. McDermott, and N. Hayes (eds.), The Ashgate Research Companion to International Criminal Law: Critical Perspectives (Routledge, 2013), at 46; M. Saif-Alden Wattad, 'The Rome Statute and Captain Planet, What Lies Between Crimes against Humanity and the Natural Environment', 19 Fordham Environmental Law Review (2009) 265; M. Orellana, 'Criminal Punishment for Environmental Damage: Individual and State Responsibility at a Crossroad', 17(4) GIELR (2005) 673.

${ }^{38}$ Freeland, supra note 19, at 202-204.

${ }^{39}$ In the Trial of German Major War Criminals, the International Military Tribunal found General Alfred Jodl guilty of war crimes associated with the scorched earth policy in Norway, Leningrad, and Moscow. Although this case may be seen as an early recognition of the criminal relevance of environmental damage caused by military tactics, the successful outcome was due to the fact that the Tribunal did not embrace the superior orders defence that Jodl claimed. See Judgment, The United States of America, the French Republic, the United Kingdom of Great Britain and Northern Ireland, and the Union of Soviet Socialist Republics v. Hermann Wilhelm Göring et al., International Military Tribunal, 30 September 1946. A different result was achieved in a trial held by the Allied Forces in Nuremberg under Control Council Law No. 10. In the Hostages Trial, General Lothar Rendulic was prosecuted, inter alia, for unnecessary destruction of enemy property, having ordered scorched earth tactics in Norway. The Tribunal acquitted Rendulic on the basis of the argument that 'he could honestly conclude that urgent military necessity warranted the decision made'. Although there was no objective military necessity, the accused was found not guilty because 'the doctrine of military necessity may be justified by one's reasonable assessment of the situation'. In other words, Rendulic was objectively wrong in his assessment of the factual scenario, however the Tribunal maintained that the standards to evaluate military necessity are 
no individual has been prosecuted or convicted for acts involving environmental harm. Whereas most scholarship points at the narrow provisions in the Rome Statute, and maintains that new norms are needed to enhance accountability, reasons beyond the limits of substantive rules should not be overlooked. These reasons relate both to the distinctive character of the phenomena under scrutiny and to some inherent features of the system of international criminal justice. This section argues that adjudicating environmental matters raises significant factual and evidentiary challenges, particularly in terms of causation and attribution. Hence, doubts arise as to whether the notion of individual criminal responsibility is adequate to confront phenomena that often have multi-factorial origins or are the result of collective actions (or of shared culpability).

A first problem relates to establishing the facts, and collecting evidence of damage, because 'the environment cannot speak for itself'. ${ }^{40}$ Pollution, for instance, has to be measured through the collection of scientific samples that satisfy the standards of a criminal trial. These data can help to assess the degree of damage caused to the environment and whether it reached the threshold that makes it criminally relevant. It is evident that any delay or change in circumstances, e.g. rainfall, may affect the process of evidence gathering. As for environmental damage caused by warfare, evidence would likely be collected at the end of the hostilities, which might be years if not decades after the injury was inflicted, raising doubts on its reliability. The Report for the ICTY Prosecutor drafted by the Committee Established to Review the 1999 North-Atlantic Treaty Organisation (NATO) Bombing Campaign in the former Yugoslavia drew attention to the issue of evidence gathering. ${ }^{41}$ The Committee noted that ' $[\mathrm{t}]$ he OTP has been hampered in its assessment of the extent of environmental damage

subjective. See Judgment, United States v. Wilhelm List et al. (Case No. 7), Military Tribunal VII, 19 February 1948.

${ }^{40}$ A. Fichtelberg, 'Resource Wars, Environmental Crime, and the Laws of War: Updating War Crimes in a Resource Scarce World', in Environmental Crimes and Social Conflict: Contemporary and Emerging Issues (Routledge, 2015), at 177.

${ }^{41}$ Committee Established to Review the NATO Bombing Campaign against the Federal Republic of Yugoslavia, Final Report to the Prosecutor, 13 June 2000, available online at http://www.icty.org/en/press/final-report-prosecutor-committee-established-review-nato-bombingcampaign-against-federal (visited 25 May 2017) ('ICTY Committee'). 
in Kosovo by a lack of alternative and corroborated sources regarding the extent of environmental contamination caused by the NATO bombing campaign'. ${ }^{42}$ On that occasion, the only available evidence was a study by the UNEP.

A second problem concerns causation, or the process of connecting a particular episode of environmental damage to the responsible subject. Environmental scholars have drawn attention to the complexity of establishing a causal relationship between a given act (or omission) and its environmentally harmful outcome, both in times of peace and war. ${ }^{43}$ Difficulties arise from the very nature of environmental harms and include the following factors: the geographical distance between the source of pollution and the damage to the environment; the time lapse between the conduct and the effects of the conduct on the environment; and, most importantly, the multi-factorial origin of environmental damage (i.e. the existence of several factors that could have caused the harmful outcome). ${ }^{44}$ This latter point is equally valid in attempting to establish the effects of certain environmental harms (e.g. the pollution of a river) on human health and other anthropocentric interests.

Attribution of environmental destruction is even more difficult in situations of armed conflict where causation of a specific injury may be uncertain, or highly contested by the belligerent parties. On this point, the International Criminal Tribunal for the former Yugoslavia (ICTY) Committee maintained that 'much of the environmental contamination which is discernible cannot unambiguously be attributed to the NATO bombing'. ${ }^{45}$ The UNEP study also found that '[p]art of the contamination identified at some sites clearly pre-dates the Kosovo conflict, and there is evidence of long-term deficiencies in the treatment and storage of hazardous waste'. ${ }^{46}$ As aptly observed by Mégret, environmental harms 'often

\footnotetext{
${ }^{42}$ Ibid., $\S 17$.

${ }^{43}$ E.g. A. Kiss, 'Present Limits to the Enforcement of State Responsibility for Environmental Damage', in F. Francioni and T. Scovazzi (eds), International Responsibility for Environmental Harm (Graham and Trotman, 1991), at 5-6.

${ }^{4}$ Ibid.

${ }^{45}$ ICTY Committee, supra note 41, $\$ 17$ (emphasis added).

${ }^{46}$ Ibid., $§ 16$
} 
lack[s] the single-event character typical of ordinary localized crime, and consequently may be much more about process than one-time occurrence' ${ }^{47}$

Further, the nature of environmental harm poses challenges for the prosecution of business actors, who are often geographically and causally distant from the commission of the 'environmental crime'. Legal tools to attribute criminal liability to corporate agents have been discussed by commentators. ${ }^{48}$ Yet the question is not just legal, but also factual. Indeed, the first step of the causal inquiry involves a factual question, described both in common and civil law systems as the "cause in fact'. ${ }^{49}$ As rightly noted by Gerry Simpson, 'with ... ecological crimes, the dispersion of culpability, the continuing legality of much structural behaviour, the sheer ubiquity of the offence, and the difficulties in teasing individual responsibility from collective action are likely to be particularly acute' ${ }^{50}$

It is acknowledged that all these problems may equally be faced by domestic courts, yet they may be more serious for international tribunals located far from the crime scene. They are also particularly acute in criminal trials, where the guilt of a particular individual must be established beyond reasonable doubt. Hence, the findings of the ICTY Committee serve as a reminder that criminal trials are technical enterprises, whose feasibility depends not just on the gravity of the alleged harmful conduct or the worthiness of the interest protected, but on the

\footnotetext{
${ }^{47}$ Mégret, supra note 1, at 222.

${ }^{48}$ E.g. N. Farrell, 'Attributing Criminal Liability to Corporate Actors Some Lessons from the International Tribunals', 8 Journal of International Criminal Justice (JICJ) (2010) 873, arguing that the doctrines of joint criminal enterprise and aiding and abetting, as developed by international criminal tribunals with regard to senior political and military leaders, could be employed to attribute responsibility to corporate executives located far from the crime scene. See also A. Batesmith, 'Corporate Criminal Responsibility for War Crimes and Other Violations of International Humanitarian Law: the Impact of the Business and Human Rights Movement', in C. Harvey, J. Summers and N. D. White (eds) Contemporary Challenges to the Law of War: Essays in Honour of Professor Peter Rowe (Cambridge University Press, 2014); K. Roberts, 'Corporate Liability and Complicity in International Crimes', in Jodoin and Cordonier Segger (eds), supra note $21,190$.

${ }^{49}$ In general, see M. Infantino, 'Causation Theories and Causation Rules', in M. Bussani and A.J. Sebok (eds), Comparative Tort Law: Global Perspectives (Edward Elgar, 2015) 279.

${ }^{50}$ G. Simpson, 'Crime, Structure, Harm', in Jodoin and Cordonier Segger (eds), supra note 21, 36, at 48 .
} 
capacity of the Prosecutor to demonstrate the guilt of an individual for the charged conduct, as a matter of fact and law.

\section{The Difficult Task of Reconciling the Goals and Remedies of International Criminal Justice with those of Environmental Protection}

A further question raised by the 2016 Policy Paper is whether it is worth having a greener ICC, in light of its mandate and predominantly anthropocentric scope. While recognizing that there is some divergence between the goals of criminal justice and environmental protection, this section nonetheless contends that the reparative component of the ICC's regime may be interpreted and developed with creativity, to address environmental matters in a meaningful way.

Traditionally, three moral and rational justifications have been advanced for punishing criminal offenders: retributivism (just desert), utilitarianism (general and special prevention), and expressivism (social disapproval and reinforcement of norms). ${ }^{51}$ Whilst in international criminal law no theory has emerged as the preferred rationale for the imposition of individual criminal sanction, ${ }^{52}$ the ICTY in Erdemović held that international criminal responsibility combines elements of deterrence, reprobation, and retribution. ${ }^{53}$ The Preamble of the Rome Statute also specifically mentions retribution and general prevention. Deterrence is achieved through retribution, based on the assumption that ending impunity for the most heinous crimes will show potential future perpetrators that they too will face justice. ${ }^{54}$ More far-reachingly, however, it is also maintained that the goals of the international criminal justice system encompass the maintenance or promotion of

\footnotetext{
${ }^{51}$ In general, see K. Ambos, 'The Overall Function of International Criminal Law: Striking the Right Balance Between the Rechtsgut and the Harm Principles', 9 Criminal Law and Philosophy $(06 / 2015) 301$.

52 R. Provost, 'International Criminal Environmental Law', in G.S. Goodwin-Gill and S. Talmon (eds), The Reality of International Law (Oxford University Press, 1999), at 441.

53 Judgment, Erdemović (IT-96-22-T), Trial Chamber, 29 November 1996, §§ 64-66.

${ }^{54} \mathrm{O}$. Triffterer (ed.), Commentary on the Rome Statute of the International Criminal Court: Observers' Notes, Article by Article (2nd edn.. Beck/Hart/Nomos, 2008), at 10.
} 
peace and security, ${ }^{55}$ establishment of a historical record of crimes ${ }^{56}$ and 'justice for victims, ${ }^{57}$ including reparative justice. ${ }^{58}$

At first, there seems to be some divergence between the goals of international criminal justice and those of environmental protection. Environmental harms are often irremediable, or at least long-lasting, thus in the words of the International Court of Justice, 'vigilance and prevention' ought to be the priority. ${ }^{59}$ The tension between the purposes, is reflected in the character of $e x$ post facto remedies. When prevention fails, and damage occurs, environmental mitigation and restoration became necessary (e.g. clean-up measures, reintroduction of flora and fauna species in a particular ecosystem).

As has been correctly observed, one of the biggest limitation of international criminal justice in the area of environmental protection concerns the inadequacy of remedies. ${ }^{60}$ Article 77 of the ICC Statute lists imprisonment, fines and forfeiture of the proceeds of crime as the applicable penalties. Considering the historical focus of international criminal justice on anthropocentric values, unsurprisingly, environmental remediation is not envisaged as a possible criminal sanction. Conversely, the 1998 Convention for the Protection of the Environment through Criminal Law of the Council of Europe explicitly establishes an obligation to restore the environment in case of conviction. ${ }^{61}$

Further, until now, international criminal tribunals have been primarily concerned with the conduct of governments, or political or military organizations.

\footnotetext{
55 ICCSt., Preamble.

${ }^{56}$ Provost, supra note 52, at 441.

${ }^{57}$ L. Moffett, 'Elaborating Justice for Victims at the International Criminal Court Beyond Rhetoric and The Hague', 13 JICJ (2015) 1.

58 C. Stahn, 'Reparative Justice after the Lubanga Appeal Judgment: New Prospects for Expressivism and Participatory Justice or 'Juridified Victimhood' by Other Means?' 13(4) JICJ (2015) 1.

${ }^{59}$ Case Concerning Gabcikovo-Nagymaros Project (Hungary v. Slovakia), International Court of Justice, Judgment of 25 September 1997, § 141 ('[t]he Court is mindful that, in the field of environmental protection, vigilance and prevention are required on account of the often irreversible character of damage to the environment and of the limitations inherent in the very mechanism of reparation of this type of damage').

${ }^{60}$ Drumbl, supra note 18 , at 327.

${ }^{61}$ Council of Europe, Convention on the Protection of the Environment Through Criminal Law, 4 November 1998, Art. 6.
} 
Only occasionally and indirectly has international criminal justice addressed the behaviour of the private sector. Yet most environmental offences are indeed the result of private actions, often committed for self-interest or enrichment. As correctly observed, "war crimes and environmental crimes represent two completely different paradigms of criminality, standing on opposite ends of the public/private crime spectrum'. ${ }^{62}$ Although the situation may be somewhat different after the outbreak of an armed conflict, where forms of collusion between private and public entities often take place, questions remain about the capacity of international criminal tribunals to fulfil their deterrent and remedial functions, at least with regard to environmental destruction, as long as the bulk of corporate activity appears out of reach.

Of course, under the existing provisions of the Rome Statute, corporations themselves cannot be held criminally liable, but there is precedent for holding business representatives accountable in international criminal law. The postWorld War II trials against Nazi industrialists are the only relevant examples. Some commentators have noted the advantage of imposing criminal liability upon individuals for environmentally harmful conduct, as opposed to other forms of enforcement such as state responsibility, because non-state actors, and most notably corporate executives, can in principle be held accountable. ${ }^{63}$ Yet, the impossibility of addressing corporate liability with adequate sanctions remains a strong limitation upon the international criminal law regime in preserving the environment and scarce natural resources.

Whilst there are inherent limitations to what international criminal justice can achieve in the field of environmental protection and remediation, it is submitted that a more proactive role for the ICC in confronting environmental destruction can still be envisaged. Prosecuting core international crimes contributes to deterring conduct harmful to the environment by raising the costs of non-compliance (including the social and reputational costs associated with

\footnotetext{
${ }^{62}$ Fichtelberg, supra note 40, at 182.

${ }^{63}$ Provost, supra note 52, at 446.
} 
sentencing). Further, it has an impact on the public consciousness, reinforcing respect for the rule of law and the fundamental interests it protects. Mark Drumbl correctly recognizes that expressivism may be the strongest reason for prosecuting 'environmental crimes' before international fora. ${ }^{64}$

One might point out that these are largely symbolic functions, and indeed they are. Hence, they should be complemented by a second, more practical contribution. In terms of remedies, pursuant to Article 75 of the ICC Statute, reparations can be ordered by the Court as a result of a conviction. It is the combination of punitive and reparative justice that distinguishes the ICC from other international criminal tribunals and that, if developed, may help to address environmental matters in a more meaningful way.

In accordance with the 2016 Policy Paper, a distinction should be made between two scenarios. First, if the defendant is found guilty of a crime 'that result(s) in the destruction of the environment', most notably Article 8(2)(b)(iv). In such a situation, it will be difficult to argue that the environment qualifies as the 'victim' of the crime and thus the beneficiary of any reparation order, especially considering the wording of Rule 85 which limits such eligible victims to 'natural persons'. Second, if the defendant is found guilty of a crime that is committed 'by means of ... the destruction of the environment', for instance a crime against humanity. In this case, individual and collective reparations can be awarded to the (human) victims who suffered any loss or injury (including impaired health or disease) as a result of the commission of the underlying environmental wrongs.

In the second scenario, a possible way to move towards more environmentally focused reparations (beyond conventional compensation for medical expenses or loss of property) may be through the appointment of experts. At the request of victims or their legal representatives, or the convicted person, or on its own motion, the ICC may appoint experts to assist in evaluating the harm to

${ }^{64}$ M. Drumbl, Accountability for Property Crimes and Environmental War Crimes: Prosecution, Litigation, and Development, International Center for Transitional Justice, November 2009, at 21 22. 
victims. The experts may also 'suggest various options concerning the appropriate types and modalities of reparations'. ${ }^{65}$ Hence, the appointment of experts may be a useful tool to secure that, for instance, collective reparations address also environmental concerns related to the commission of the anthropocentric offences (e.g. the costs incurred to clean-up a river or to restore damaged natural resources).

In sum, there is some tension between the goals and remedies of international criminal justice and those of environmental preservation that, coupled with factual and evidentiary obstacles, may in part explain the limited engagement (until now) of international criminal tribunals with environmental wrongs. It is submitted, however, the adoption of creative approaches to reparations in the ICC's future practice may be a sound way to move forward. By doing so, the ICC would complement its predominant retributive paradigm, which remains limited in addressing environmental matters, and contribute in practical ways to accountability.

\section{Conclusions}

The protection of the environment (and thereby of humanity) from particularly harmful conduct is not completely alien to the ICC's purview, although it has been neglected until now. As observed by the late Judge Christopher Weeramantry, who often took a progressive view on environmental protection, international obligations with respect of the environment 'may range from obligations erga omnes, through obligations which are in the nature of jus cogens, all the way up to the level of international crimes' ${ }^{66}$

This article argued that, in addition to the limitations of the substantive law, the significance of the 2016 Policy Paper ought to be assessed against factual and structural concerns. The essay sought to maintain a balance between optimistic and pessimistic views of some of the realities which may inform the practical

\footnotetext{
${ }^{65}$ Rule 97(2) ICC RPE,

${ }^{66}$ C. Weeramantry, Universalizing International Law (Martinus Nijhoff Publishers, 2004), at 451.
} 
implementation of the Prosecutor's case selection strategy. The challenges identified in the paper are real, but so are the opportunities associated with the OTP's 'green shift'. Beyond the symbolic and expressivist value of adjudicating environmental matters before the ICC, there are real possibilities for interpreting existing provisions in a greener fashion, developing principles on causation and broadening the reparative arsenal of the Court to encompass environmentally meaningful measures. Ultimately, in what might be seen as difficult times, the 'rebranding' of the OTP's priorities, from solely prosecuting government officials and leaders of armed groups for war crimes or political repression to more diffuse harms caused by mid-level agents and, hopefully, corporate actors, may give new moral strength to the institution.

At the same time, it is crystal clear that the ICC will never be able to do justice to all forms of environmental destruction, as it is evident that criminal accountability is just one dimension of 'environmental justice', which embraces elements of retributive, corrective and distributive justice. ${ }^{67}$ The ICC can only address the symptoms of the world's inequalities, and not the structural and root causes in the economic, social and ecological fields that gave rise to such symptoms. The system of international criminal law has its limits in producing the transformations necessary to achieve 'environmental justice' in full. Yet, in the battle between the international criminal law believers and sceptics, for the time being, it is perhaps a wise move to take a moderate stand.

\footnotetext{
${ }^{67}$ J. Ebbesson, 'Dimensions of Justice in Environmental Law', in J. Ebbesson and P. Okowa (eds), Environmental Law and Justice in Context (Cambridge University Press, 2009), at 4.
} 